\title{
Researchers develop alternatives to methyl bromide fumigation
}

$\mathrm{T}$ me is running out for California grow ers who still use methyl bromide. This soil fumigant is just short of a miracle for pest management - a single treatment before planting controls nematodes, diseases and weeds. But methyl bromide is also a health and environmental hazard, and is being phased out under an international ban. To help growers make the inevitable transition, UC and U.S. Department of Agriculture (USDA) researchers just spent 5 years testing methyl bromide alternatives for key western crops with a $\$ 5$ million grant from the USDA. The program's research is presented in the current and the coming October-December issue of California Agriculture.

"One goal of the program was to identify methyl bromide alternatives that were immediately useful and economically feasible," says Greg Browne, a USDA plant pathologist at UC Davis who was project coordinator for the research program. "Another was to foster development of non-fumigant strategies for managing soilborne pests."

Growers have used methyl bromide since the 1960s to effectively sterilize fields before planting. But this toxic gas is so volatile that more than half of the amount injected into soil can eventually end up in the air. When methyl bromide rises high in the atmosphere, it contributes to thinning of the ozone layer (the layer that shields us from ultraviolet radiation). In 2005, developed countries banned methyl bromide under the Montreal Protocol, an international treaty signed in 1987 to protect the stratospheric ozone layer.

Even so, the treaty still allows limited use of methyl bromide in certain cases today. These include critical use exemptions for strawberries, almonds and other crops that lack alternatives that are both effective and affordable, as well as quarantine and preshipment exemptions for rootstock,

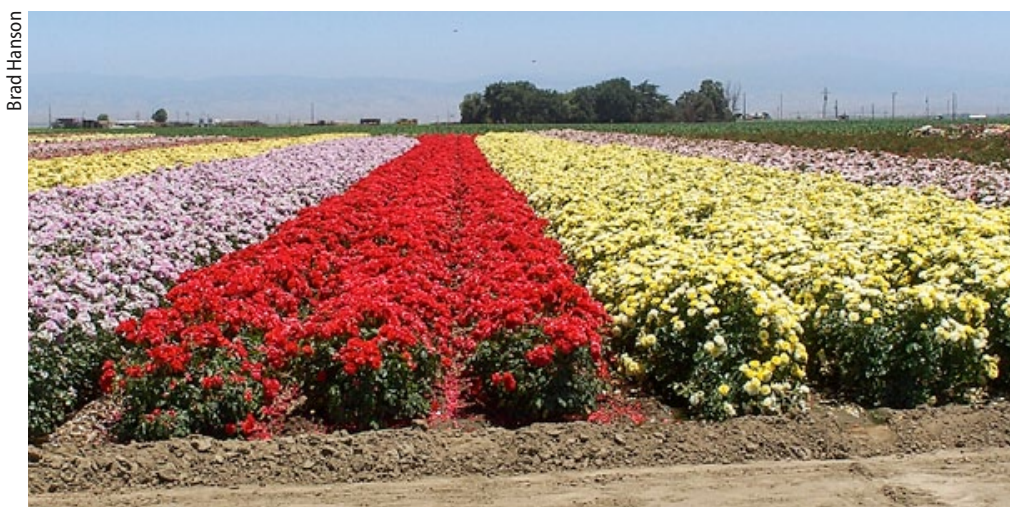

Alternative fumigants such as 1,3-D may be the best option in the short term for nursery stock, which must be completely nematode-free to meet California's phytosanitary certification requirements. bulbs and other nursery crops that could spread pests to new places. This authorized use shrinks each year, however, and will soon end. In the United States, recent methyl bromide use is down sharply from the 1991 baseline of 28,000 tons. The nationwide exemption for 2013 is $2.2 \%$ of baseline, or about 620 tons, and in 2014 this will drop further to $1.7 \%$ of baseline, or about 480 tons. The exemption for 2015, if any, is unknown. For comparison, California alone used 3,550 tons of methyl bromide in 2004, the year before it was banned.

Other restrictions on methyl bromide use include seasonal bans to cut air pollution, and the requirement of buffer zones to protect people's health. While methyl bromide depletes the protective ozone in the stratosphere, it adds to groundlevel ozone or smog. Thus, its use is prohibited during the warm months in parts of the state with poor air quality, including the San Joaquin Valley and Ventura County. Moreover, methyl bromidefree buffers are required around sites that are hard to evacuate, such as schools, hospitals and jails, because high concentrations of this fumigant can cause lung, eye and skin damage as well as respiratory and central nervous system failure.

\section{Finding alternatives}

Most of the dwindling U.S. methyl bromide allotment goes to California and Florida, so the USDA Agricultural Research Service launched twin research initiatives to help find alternatives for growers in these regions. "The programs focused on the most important needs in the west and southeast," says Browne. "The crop mixes were based on the views of growers and other stakeholders." The western program, called the Pacific-Area Wide Integrated Methyl Bromide Alternatives Program, includes production crops such as grapes, strawberries and tree nuts as well as nursery crops such as cut flowers, forest trees and sweet potatoes. The South Atlantic Area Extension Program for Methyl Bromide Alternatives, the southeast program, includes crops such as strawberries, tomatoes, cucumbers and peppers.

Finding alternatives is a challenge because methyl bromide sterilizes soil so well. "Methyl bromide is a one-shot control. It does so much that it's hard to find a true replacement," says Brad Hanson, a UC Cooperative Extension (UCCE) weed specialist at UC Davis. In addition, the best alternative varies, depending partly on the primary benefit a particular crop gets from methyl bromide. For example, the biggest problems for production crops may be diseases or weeds. But the biggest problem 
for nursery stock is nematodes, tiny worms that can damage plants by eating them and by spreading diseases. Nursery stock must be completely nematode-free to receive the certification required by the state of California.

Another challenge is that while other fumigants can be substituted for methyl bromide, only a few are approved, and their use is also restricted. Like methyl bromide, alternative fumignats have seasonal bans and buffer requirements. Moreover, alternative fumigants can also have tight limits on total use. These restrictions are likely to increase, intensifying the urgency to find non-fumigant solutions.

\section{Optimizing other fumigants}

Despite their drawbacks, alternative fumigants may be the best option - at least in the short term - for many crops with methyl bromide exemptions. This is particularly true for nursery products. "They have a higher bar because they have to get phytosanitary certification," says Hanson, who led a team that focused on bareroot rose, tree and vine nursery stock grown in the ground. "If any nematodes are found, growers have to destroy the whole block of plants," he adds. Losses can reach 20,000 plants and, for trees and vines, can exceed $\$ 50,000$ per acre. Perennial nursery stock is vital to California's fruit, nut and vineyard industries, and supplies more than $60 \%$ of the rose plants and fruit and nut trees sold nationwide.

Methyl bromide is a small molecule that spreads quickly even in soil with fine pores, which means it controls nematodes even in soil that is wet or full of clay. In contrast, other fumigants are less forgiving of soil conditions. "We asked how we could make them work better," Hanson says. The team tested an alternative fumigant called 1,3-dichloropropene (1,3-D) which controls nematodes well in sandy soil but often doesn't spread evenly enough in clay. "In less than ideal conditions, it can leave pockets of untreated soil," Hanson says. In addition, 1,3-D doesn't control weeds as well as methyl bromide, so growers will have to incur the extra expense of additional tillage, hand weeding or herbicides. Another disadvantage is that this alternative fumigant may not control soil diseases as well as methyl bromide.

That said, the researchers showed that 1,3-D can control nematodes effectively in fine soil as long as it has been properly prepared. This includes tilling deeper to dry and pulverize the soil, injecting the fumigant deeper, and using tarps to keep more of the fumigant in the soil. When allowed by county regulations, the team also recommends combining 1,3-D with other fumigants called chloropicrin and metam sodium. "Although this is not a simple solution, now growers will have information on how to use these alternatives once their methyl bromide exemptions expire," Hanson says.

\section{Reducing emissions}

Because using fumigants is unavoidable for nursery stock in the short term, Hanson was also on a team that focused on reducing their emissions from the soil. Besides lessening their environmental impact, keeping these volatile gases out of the atmosphere will help growers meet the tighter air quality regulations expected in the future. This will help extend the

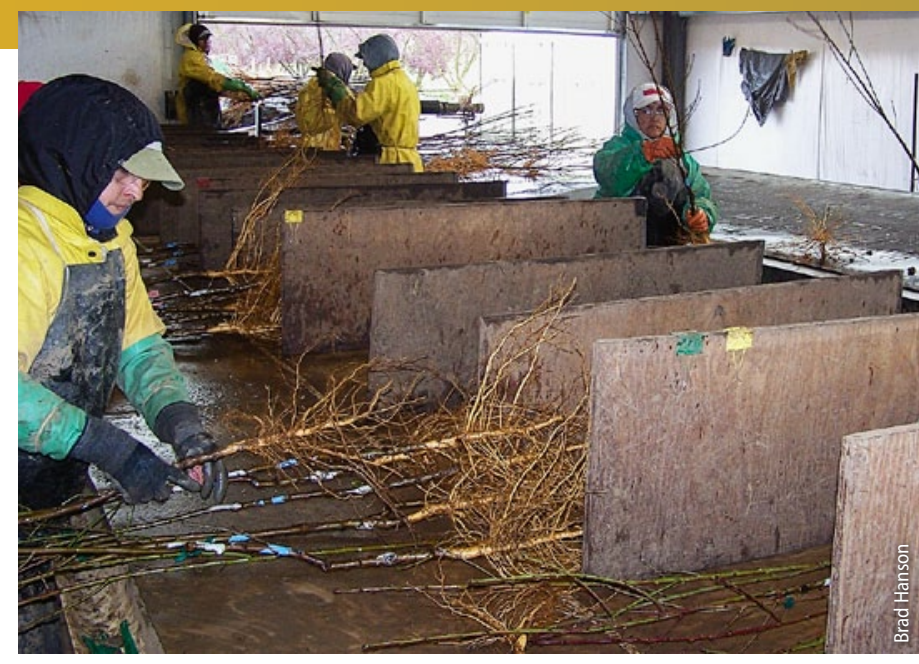

Workers sort and grade bareroot nursery stock. California supplies most of the rose plants and fruit and nut trees sold nationwide.

agricultural use of fumigants until effective non-fumigant alternatives are found.

The emissions reduction team tested a new kind of tarp that has five or more layers to help keep fumigants in the soil. This multi-layer tarp, called totally impermeable film (TIF), traps 90\% of the fumigant. Over time, the trapped fumigant breaks down or is degraded into harmless compounds by microbes. TIF also boosts the fumigant's concentration in soil and helps it spread through the field better, making this treatment more effective. "This might cut fumigant use by about half, which would solve a lot of problems," says Suduan Gao, a USDA soil scientist in Parlier who led the team.

The high-tech tarp also has a potential downside, though. A spike of toxic gas is released if the TIF is cut open for planting before the fumigant has broken down, which can take two weeks or more depending on the soil conditions, and the application method and rate. "We're now working on safe use," Gao says. "The goal is to keep the fumigant under the tarp long enough that there won't be a surge in emissions."

\section{Targeted injection}

Another way of using less fumigant is to apply it only where needed, rather than on an entire field or all along the length of each row. Almond and other stone fruit growers use methyl bromide primarily to control Prunus replant disease, a soilborne disorder that stunts the trees' early growth. This greatly diminishes crop yields - and profits - over the life of the orchard. Almonds alone are valued at close to $\$ 4$ billion a year, and were California's number two commodity in 2011. Before replanting an orchard, growers typically inject methyl bromide in a continuous swath down each row.

But it turns out that the entire row doesn't have to be fumigated to control Prunus replant disease. The USDA's Browne led a team that tested spot treatments, which entail injecting alternative fumigants only into the sites where trees would be planted. "We wanted to see how little we could use," he says. To target spot treatments to future tree sites, a GPS-based system was developed under the direction of Shrini Upadhyaya, a professor in the Department of Biological and Agricultural Engineering at UC Davis.

While almond and other stone fruit growers currently fumigate about half of an orchard's area before replanting, spot 
treatments can decrease that to about a tenth or a fifth. "Spot treatments provided adequate control of Prunus replant disease and may be very helpful to growers needing to use less fumigant for costs savings or regulatory restrictions," Browne says. He is now working to develop almond and stone fruit rootstocks that resist Prunus replant disease. Ultimately, this could help these growers stop using fumigants altogether, as long as their orchards don't have nematode problems.

However, nematodes are a problem in about a third of California's almond and stone fruit orchards. These pests eat the roots of trees, stunting their growth, and populations can build over the lifetime of an orchard, reducing yields. Growers with nematode problems currently fumigate continuously down the entire row. However, as long as they use nematode-resistant rootstock, they could use the intermittent spot treatment instead.

\section{Fumigation not needed?}

While many production systems with methyl bromide exemptions are likely to switch to other fumigants, the researchers found one that may not need fumigation at all. Sweet potato growers have two production systems: commercial fields, and hotbeds where they raise their own transplants. Growers had already begun using an alternative fumigant on commercial fields due to the cost of methyl bromide. But, when the study began, they still used methyl bromide to prepare hotbed soil. Sweet potatoes, which were the number five commodity in Merced County in 2011, needed an alternative fast because their exemption was set to end in 2012.

"The presumption was that it would be a disaster, with rumors of 75\% crop loss," says Scott Stoddard, a UCCE farm advisor in Merced County who led a team that focused on sweet potato hotbeds. "But no one had ever tested what methyl bromide was actually doing, or not doing, in this system," he adds. The team found that even with no treatment, plant diseases were not a problem. Likewise, nematodes were not a problem, presumably because hotbed production is during the early spring when populations of this pest tend to be low.

However, without methyl bromide, sweet potato hotbeds did have a lot of weeds. But the team found that these can be controlled with herbicides, showing that fumigation is not needed in hotbeds. "We found an alternative that everyone's happy about - it's less expensive, works and has no use restrictions," Stoddard says. "This approach has been rapidly adopted by the industry."

\section{Beyond fumigants}

Likewise, the strawberry research team focused on ways to avoid fumigation altogether. This could allow strawberry production on prime growing land that is too close to urban areas for fumigation. "Strawberries like the same climate as people do," says Steve Fennimore, a UCCE weed specialist in Salinas who led a team that focused on strawberries. "They do best within a few miles of the ocean, which is also where a lot of people live."

Methyl bromide is used on about a third of California's strawberry acreage, where soilborne pathogens are high.
"Strawberries are incredibly susceptible to disease," Fennimore says. "They turn brown and die." Valued at nearly $\$ 2$ billion per year, strawberries were the state's number six commodity in 2011. While strawberries can be grown with other fumigants, these are also so heavily regulated that growers are struggling to replace the methyl bromide currently being used. Ultimately, strawberry growers may have to use a mix of fumigant and nonfumigant treatments.

At the request of the California Strawberry Commission, the team explored non-fumigant alternatives including production without soil. For example, strawberries are grown in substrates such as peat moss or coconut hull fiber in Europe. These systems are challenging, however, requiring irrigation and fertilization several times a day.

The team also tested controlling soil pathogens with steam sterilization. "Instead of understanding soil, we've just been fumigating it," Fennimore says. "Using physical tools is a different approach." The team tested a steam rig that heats soil to $160^{\circ} \mathrm{F}$ in just 90 seconds and keeps it hot for 20 minutes, long enough to kill soil pests as effectively as methyl bromide. The rig can treat an acre in 15 hours, and the team is working to bring that down to $4-8$ hours.

To give strawberry growers more non-fumigant options, the team also tested controlling soil pests and weeds with mustard seed meal. This natural material contains a compound called allyl isothiocyanate that sterilizes soil but is not toxic to people. So far, a combination of mustard seed meal and steam treatment is promising.

Another natural approach is to control diseases and possibly weeds with the anaerobic microbes that live in soil. Called anaerobic soil disinfestation, this method entails increasing anaerobic microbe populations by feeding them a carbon source such as rice bran, and then making the soil anaerobic by covering it with plastic and keeping it wet. Short-term findings on small plots suggest that anaerobic microbes may control strawberry diseases nearly as well as fumigation.

\section{Program website}

The research teams documented their findings in a 100-page website (http://ucanr.edu/sites/ PAWMBA/), which will help growers find the methyl bromide alternatives that work best for them.

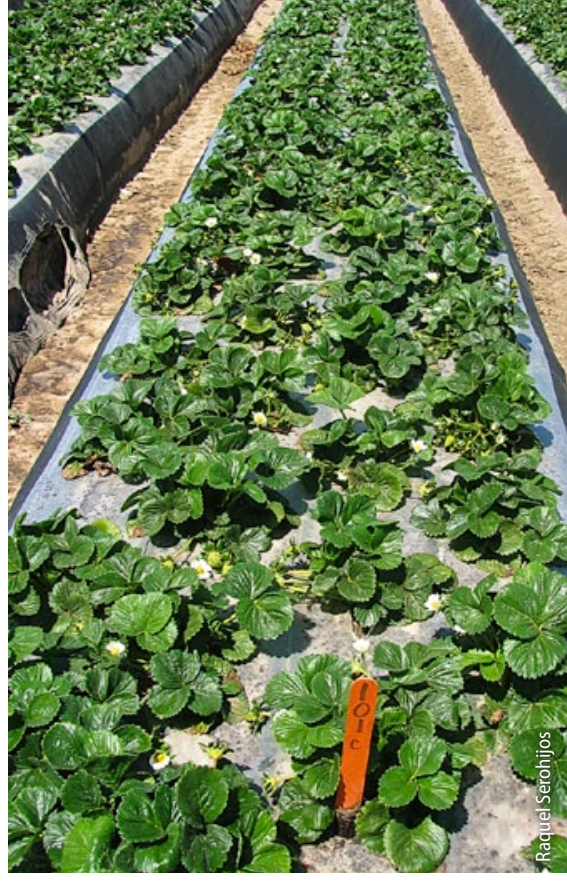

Strawberries growing in coir, a soil-free substrate that does not need fumigation.
"We wanted to give them a place to find out what to expect when they make the switch," says project coordinator Browne. By identifying alternatives that are both effective and economical, this research will help ease the transition to post-methyl bromide production of key crops in California. - Robin Meadows 